International Journal of Linguistics, Literature and Translation

ISSN: 2617-0299 (Online); ISSN: 2708-0099 (Print)

DOI: 10.32996/ijltt

Journal Homepage: www.al-kindipublisher.com/index.php/ijllt

IJLLT

\title{
The Interpersonal Meaning on the Covid-19 Vaccination News in Indonesia: A Systemic Functional Linguistics Study
}

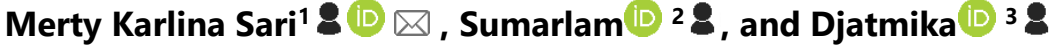 \\ ${ }^{1}$ Magister of Linguistics, Faculty of Cultural Science, Sebelas Maret University, Surakarta, Indonesia \\ ${ }^{23}$ Professor of Linguistics, Faculty of Cultural Science, Sebelas Maret University, Surakarta, Indonesia \\ $\triangle$ Corresponding Author: Merty Karlina Sari, E-mail: mertykarlinasari@gmail.com
}

\author{
ARTICLE INFORMATION \\ Received: July 07, 2021 \\ Accepted: August 22, 2021 \\ Volume: 4 \\ Issue: 8 \\ DOI: $10.32996 /$ ijllt.2021.4.8.15
}

\section{KEYWORDS}

Interpersonal Meaning, Covid-19

Vaccination, News, Status, Affect,

Contact

\section{ABSTRACT}

Some media use interesting titles in their news. Like the online media m.republika.co.id which uses the verbs "meminta (ask)" and "diminta (requested)" in its reporting. This study will reveal the interpersonal meaning of m.republika.co.id entitled "Jokowi Minta Daerah Kawal Vaksinasi Covid-19". This research is descriptivequalitative research that will describe the findings and describe the status, affect, and contacts that are part of the focus of this research. The methods and techniques used in this study are data analysis methods proposed by Spradley (1980) namely domain, taxonomy, and componential analysis. The results of the study indicate that m.republika.co.id positions itself as a party that provides information and places readers as members of the academic community who are expected to also have an interest in the information. This is evidenced by the dominance of the proposition of the proposal, the dominance of positive polarity, the dominance of congruent lexis rather than incongruent, and also the use of a complex clause system that describes the closeness of the distance between the writer and the reader.

\section{Introduction}

This research stems from online media coverage, namely m.republika.co.id regarding the Covid-19 vaccine which conveys the news using the verb «ask» which means asking for services or is referred to as a proposal in the study of Systemic Functional Linguistics. That is, the author or participant in the text places the reader or other participant unequal. Therefore, the researcher is interested in this research and will examine the interpersonal meaning in reporting the Covid-19 vaccine on Indonesian online media, namely m.republika.co.id. This study aims to reveal the interpersonal meaning in the m.republika.co.id and focuses on status, affect, and contact, a study of interpersonal meaning.

Interpersonal meaning embodies the meaning that is built from the interaction between participants in social interaction. Social interaction is a form of action from the perpetrator to others. The relationship between speakers or writers with listeners or readers can be realized in the form of clauses as an exchange, both propositions (giving and demanding information) and proposals (giving and demanding goods and services). The proposition is in the statement and question clause while the proposal is in the offer and command clause (Halliday \& Hasan, 1985). Halliday and Matthiessen (2004) argue that interpersonal meaning has a relationship with the speaker or writer's attitude and point of view and the way he maintains social relations with the recipient to achieve his communicative goals.

Research on the topic of interpersonal meaning has been conducted by Huang (2014), Olusanya (2014), and Koutchade (2016). Huang's research (2014) aims to reveal the meaning of interpersonal in a political interview. However, in his research, Huang (2014) has not focused on status, affect, and contact because it has not explained the role or social status relationship between participants, has not explained the assessment of participants to other participants, and has not explained the level of participation of participants in the event while the Olusa research (2014) revealing interpersonal meaning in 8 political

\section{K C AL-KINDI CENTER \\ $\mathbf{R}$ D FOR RESEARCH AND DEVELOPMENT}

Your gateway to world-class research

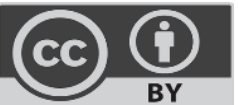

Published by Al-Kindi Center for Research and Development, London, United Kingdom. Copyright (c) the author(s). This open access article is distributed under a Creative Commons Attribution (CC-BY) 4.0 license 
advertisements by analyzing the MOOD system and modalities. This shows that the research has not focused on status, affect, and contact and has not described the dominance between the 2 poles in the discourse, which is the core of interpersonal meaning analysis that aims to determine differences in the relationship of roles or social status in a discourse. Meanwhile, Koutchade's research (2016) focuses on the function of interpersonal meaning as a means of exchanging meaning in the drama entitled "A Play of Giants" by revealing the use of the MOOD system and modalities as well as explaining the function of the MOOD system and modalities in the drama and has not described the relationship between roles and social status, participant ratings of other participants, and level of participant involvement in the text.

Other interpersonal meaning research with various data sources has been conducted by Nezhard and Tavakoli (2013), Chafidzoh (2020), Khaofia (2018), Hidayat, Abrizal, \& Alek (2018), \& Mulia (2015). Nezhard and Tavakoli (2013) aims to reveal the use of polarity in Persian while Mulia's (2015) research focuses on the function of interpersonal meaning as a means of exchanging meaning in the language used by Housekeeping and Food and Beverage staff. Meanwhile, Chafidzoh (2020), Khaofia (2018), Hidayat, Abrizal, \& Alek (2018) used different data sources. Chafidzoh (2020) aims to examine the use of MOOD system options in classic Arabic humor conversations, while Khaofia (2018) aims to identify the type of modality used in a talk show and research conducted by Hidayat, Abrizal, \& Alek (2018) aims to investigate and investigated the interpersonal meaning of the product 'YOUC1000' in Indonesian television advertisements. In their research, Chafidzoh (2020) and Khaofia (2018) have not described the author's assessment of other participants while Nezhard \& Tavakoli (2013), Mulia (2015), and Hidayat, Abrizal, \& Alek (2018) have not described the relationship between roles and social status, participant's assessment of other participants, and the level of participant involvement in a discourse.

\section{Methodology}

This type of research is descriptive-qualitative. The qualitative method was carried out because this study will collect and analyze news text data in m.republika.co.id using the theory of Systemic Functional Linguistics proposed by Halliday \& Matthiessen (2014). This approach is used to investigate the interpersonal meaning of the online news portal regarding the Covid-19 vaccine news in Indonesia by looking at the MOOD system, polarity, modality, lexis system, and clause system in the Covid-19 vaccine news which is accessed from the Online portal m.republika.co.id with the title "Jokowi Minta Daerah Kawal Vaksinasi Covid-19". Furthermore, this research is also descriptive because it describes the findings. This is in accordance with Moleong (2012) opinion, which says that the description is one of the characteristics of qualitative research because in qualitative research reports, there are data quotes accompanied by descriptions of the analysis. The author analyzes and describes the findings of how interpersonal relationships and interactions are in the news of the Covid-19 vaccine in Indonesia.

This study uses content analysis techniques because the data source comes from the website m.republika.co.id. This research data are in the form of words and clauses that realize interpersonal meanings in reporting the Covid-19 vaccine in Indonesia from a news text with the title "Jokowi Minta Daerah Kawal Vaksinasi Covid-19". In addition, context is also an important part of investigating data because context determines data definition (Mahsun, 2012). Furthermore, the data that has been filtered and collected will be analyzed using analytical techniques (Spradley, 1980) in the form of domain analysis, taxonomic analysis, componential analysis, and analysis of cultural themes in order to reveal interpersonal meanings in reporting the Covid-19 vaccine in Indonesia.

\section{Resullts and Discussion}

\section{A. Results}

Based on the previously mentioned research focus, linguistic sources (Mood structure, MOOD system, modality, polarity, lexis, lexis system, clause system, text structure and genre) are studied based on the social culture of the news. As a journalist product, news texts are categorized based on the media domain (text from the Online news portal m.republika.co.id. Then, news texts are classified by sub-domains or text structures. The text analyzed is recount text and the structure of recount text consists of title, orientation, sequence of events I, sequence of events II, sequence of events III, and reorientation. Examples of domain analysis in m.republika.co.id are as follows.

\section{1) Contoh Analisis Struktur Mood pada Analisis Domain}

a) Sekali lagi, kawal program vaksinasi dengan detil Covid-19 (RPL/Reorientation/C44)

b) Pada tahap awal, vaksinasi diberikan kepada para tenaga kesehatan (RPL/Sequence of Event II/C26)

Data (a) is an example of a proposal clause that is in the reorientation stage and is identified as an imperative clause that functions as a proposal since the participant in the text ordered something from another participant in the text. This is in line with Halliday's (2014) opinion that imperative clauses produce two types of messages, namely ordering others to do something and inviting others to do something together. In this case, the participant in the text is President Joko Widodo as the President of the State of Indonesia who gives orders to all local governments in Indonesia to supervise the implementation of the 
vaccination process in Indonesia. Meanwhile, data (b) is a propositional clause in the stage of the sequence of events II and is identified as a declarative indicative that functions as a proposition since there is a subject followed by polarity and serves to provide information to the reader. The following is an example of the MOOD system in the clause in the Covid-19 vaccine news.

(a) Sekali lagi, kawal program vaksimaasi dengan detil

\begin{tabular}{|l|l|l|l|}
\hline Sekali lagi & kawal & program vaksinasi & dengan detil \\
\hline Adj & P & Pel & Adj \\
\hline Residu & & \\
\hline
\end{tabular}

Imperative; Proposal

(b) Pada tahap awal, vaksinasi diberikan kepada para tenaga kesehatan.

\begin{tabular}{|l|l|l|l|}
\hline Pada tahap awal & vaksinasi & diberikan & kepada para tenaga kesehatan \\
\hline Adj & S & Pol/P & Adj \\
\hline Re & Mood & -sidu & \\
\hline
\end{tabular}

Indikative: Deklarative: Proposition

\section{2) Contoh Analisis Modalitas pada Analisis Domain}

a) Pemerintah sendiri menargetkan lebih dari 181 juta masyarakat akan mendapatkan vaksinasi (RPL/Sequence of Event I/C22)

b) ini harus ngerti semuanya (RPL/Sequence of Event II/C37)

Data (a) is an example of a clause with a median level of modality for inclination that is in the stage of the sequence of events I and is used to inform that the government has a vaccination target, namely that more than 181 million Indonesians must be vaccinated with the aim of creating community immunity. Meanwhile, data (b) is an example of a high-level modality for inclination-must exist at the stage of the sequence of events II and is used to inform what information must be understood regarding the distribution of Covid-19 vaccines such as places that must take precedence in the vaccine distribution process, vaccination targets and so on and is also used to emphasize information regarding the distribution of Covid-19 vaccines.

The second analytical tool is taxonomic analysis or the use of categories from the theory / approach used, namely Systemic Functional Linguistics to reduce and organize data about linguistic phenomena that occur (Santosa, 2017). This aims to obtain a more detailed classification of data selected through domain analysis. For example, the mood structure in the domain analysis is then classified as giving information (GI), demanding information (DI), giving goods and services (GGS), and demanding services (DS). In the same way, modalities in the taxonomic analysis are classified through modulation (probability and usuality) and modalization (obligation and inclination) in taxonomic analysis. Meanwhile, the lexis system is classified into descriptive, attitudinal, congruent, and incongruent, while the clause system is classified into minor, simple, and complex clauses. Then, this kind of analysis is simultaneously applied to all data by category. Taxonomic analysis determines classification according to categories: mood structure, modality, polarity, lexis, lexis system and clause system.

The next analysis is componential analysis. Santosa (2017) said that relationships between categories in the previous domain and taxonomy were built to show relationship patterns, interaction patterns, and behavior patterns in componential analysis. In the componential analysis, the contrasting elements are sorted and further categorized as relevant. Analysis of mood structure, modality, polarity, lexis, lexis system, and clause system are categorized according to the research focus. This research is interpersonal meaning research that focuses on status, affect, and contact analysis. Therefore, the analyzes will be categorized based on status, affect, and contact to find out patterns and interpret the realization of interpersonal meaning in the news of the Covid-19 vaccine in Indonesia. The componential analysis table is as follows:

Table 1. Componential Analysis in the News on m.republika.co.id

\begin{tabular}{|c|c|c|c|c|c|c|c|c|c|c|c|c|c|c|c|c|c|c|}
\hline \multirow[t]{4}{*}{ News } & \multirow{4}{*}{$\begin{array}{c}\text { Text } \\
\text { Structure }\end{array}$} & \multicolumn{8}{|c|}{ Status } & \multicolumn{4}{|c|}{ Affect } & \multicolumn{5}{|c|}{ Contact } \\
\hline & & \multicolumn{4}{|c|}{ MOOD System } & \multicolumn{4}{|c|}{ Modality } & \multirow{2}{*}{\multicolumn{2}{|c|}{ Polarity }} & \multirow{2}{*}{\multicolumn{2}{|c|}{ Lexis }} & \multirow{2}{*}{\multicolumn{2}{|c|}{$\begin{array}{c}\text { Lexis } \\
\text { System }\end{array}$}} & \multirow{2}{*}{\multicolumn{3}{|c|}{ Clause System }} \\
\hline & & \multicolumn{2}{|c|}{ Proposition } & \multicolumn{2}{|c|}{ Proposal } & \multicolumn{2}{|c|}{ Moda } & \multicolumn{2}{|c|}{ Modu } & & & & & & & & & \\
\hline & & $\mathrm{Gl}$ & $\mathrm{DI}$ & GGS & DGS & Prb & Usl & Obl & $|c|$ & $\mathrm{P}$ & $\mathrm{N}$ & $\mathrm{D}$ & A & Con & Inc & Min & Sim & Com \\
\hline \multirow[b]{3}{*}{ RPL } & Title & 2 & - & 1 & 1 & 1 & - & - & - & 3 & - & 7 & 2 & 6 & 3 & - & - & 2 \\
\hline & Orientation & 3 & - & 2 & 1 & - & - & - & - & 6 & - & 14 & 3 & 11 & 6 & - & - & 3 \\
\hline & $\begin{array}{l}\text { Sequence } \\
\text { of Event I }\end{array}$ & 7 & 2 & - & 3 & - & - & - & 1 & 8 & - & 19 & 2 & 16 & 5 & - & - & 3 \\
\hline
\end{tabular}




\begin{tabular}{ccccccccccccccccccccc}
\hline $\begin{array}{c}\text { Sequence } \\
\text { of Event III }\end{array}$ & 5 & - & - & - & - & - & - & 2 & 3 & - & 10 & 2 & 7 & 5 & - & 1 & 2 \\
& & & & & & & & & & & & \\
\hline Re & 3 & - & - & 3 & - & - & - & 1 & 2 & - & 11 & 2 & 8 & 5 & - & - & 1 \\
\hline Total & 30 & 2 & 3 & 14 & 1 & - & - & 5 & 29 & - & 76 & 17 & 64 & 29 & - & 1 & 14 \\
\hline
\end{tabular}

Based on table 1 above, the author uses a dominant proposition clause rather than a proposal clause. Proposition clauses are mostly found in the sequence of events II. The exchange of information as many as 32 propositions was realized in all stages of the news on m.republika.co.id while 17 proposals were only not realized in the sequence of events III. It can be said that the author wants to focus on giving information rather than demanding information or goods and services. Then, the frequency of modalities in the table describes that the author applies not all types of modalities. Frequency modulation ( 0 obligation, 5 inclinations) with modalization (1 probability, 0 usuality). But the author applies different degrees of modality in his reporting. High-level modalities for inclination-harus and high-level modalities for probability-dipastikan, median-level modalities for inclination-akan, and low-level modalities for inclination-dapat. Although there are no modalities at all stages of the text, the dominance of modulation in news texts means that the writer gives certain obligations to the readers.

Table 1 above also describes the use of polarity in the text. The author uses positive polarity and does not use negative polarity in his reporting. In addition, it was also described that descriptive lexis (76 lexis) were used more often than attitudinal lexis (17 lexis). This can be proven at every news stage, where the descriptive lexis is more dominant than the attitudinal lexis. In addition, in terms of congruence, congruent lexis (64 lexis) are more dominant than incongruent lexis (29 lexis). This can also be realized at every news stage, where the number of congruent lexis is more dominant than the number of incongruent lexis. Finally, complex clauses (14) are more dominant than the number of simplex clauses (1) and no minor clauses are found. Complex clauses are realized in all stages, namely title, orientation, sequence of events I, sequence of events II, sequence of events III, and reiteration while simplex clauses are only applied in sequence III. The dominant complex clause indicates that the author uses an oral style in conveying his thoughts.

\section{B. Discussion \\ 1) Status}

Status in the interpersonal meaning relates to the relationship of roles and social status (hierarchical/vertical and nonhierarchical/horizontal). Santosa (2003) explains that in the analysis, social status and role relationships are explained what participants are playing social roles, for example the roles and status of participants are more authoritarian, closed like superiorssubordinates, doctor-patients and so on or maybe more democratic, open like members of parliament, between lecturers or between students (Martin, 1992). This is in line with Martin's opinion (in Santosa, 2003) which states that status shows the relationship between the communicator and the communicant whether the relationship is hierarchical or parallel, whether the same or not, close or distant. Status is correlated with power between participants, while distance is related to the relationship between participants such as relatives and friends who have a close relationship while the president and citizens have a distant relationship.

Table 1 of the componential analysis in the news on m.republika.co.id describes that the news on the Covid-19 vaccine with the title "Jokowi Minta Daerah Kawal Vaksinasi Covid-19" applies a dominant declarative indicative clause as a proposition for exchanging information. This shows that the writer conveys his thoughts without giving any power to the readers. Thus, the author places the reader as an observer. In line with that, Santosa (2003) states that the purpose of a writer compiling a text using the dominant proposition clause is to determine his own stance (the reader's stance). Thus, the writer maintains the same relationship with the reader.

In the title of the news, President Joko Widodo as President of the Republic of Indonesia demands services from the Regional Government to oversee the Covid-19 vaccination in Indonesia through the use of indicative and declarative clauses. In terms of the title, the author also applies a proposal clause. The use of the proposed clause is also found at the stage of orientation sequence, an event I, sequence of events II, and reorientation. At these stages, President Joko Widodo demanded the services of all regional governments to monitor the distribution of the Covid-19 vaccine in Indonesia.

On the other hand, status can also be checked through modalities (Santosa, 2003). The table describes that news on m.republika.co.id applies more dominant modulation than modalization. Modulation is applied to the stages of the sequence of events I, the sequence of events II, the sequence of events III, and reorientation. An example of the application of modulation is the must-inclination which is a modality of high degree. This modality means that President Joko Widodo gives certain obligations to all local governments in Indonesia. 


\section{2) Affect}

Affect relates to the speaker's feelings or assessment of the topic being discussed. According to Santosa (2003) the affect relates to the description of a participant's assessment to other participants. This assessment generally consists of a positive assessment and a negative assessment. A positive assessment can be seen if one of the participants supports, flatters, agrees and appreciates the other participants, while a negative assessment can be seen if one of the participants is criticizing, cornering, mocking, blaming and so on. Djatmika (2012) argues that the assessment can be aimed at text users or participants in the text.

The assessment of participants in the news text can be described through the use of positive polarity which means positive and the absence of negative polarity. That is, all assessments of the authors or participants in the text are positive. In addition to polarity, to determine the assessment of the author or other participants in the text, it can also be seen through the use of the attitudinal lexis and descriptive lexis. Based on the data in table 1 describes that the use of descriptive lexis is more dominant than attitudinal lexis. That is, the author focuses more on describing and providing information rather than giving opinions to readers.

\section{3) Contact}

Contact refers to the level of involvement among participants in the text thus indicating the proximity of the distance (Martin, 1992). Djatmika (2012) says that the use of language familiarity indicates the level of involvement. Santosa (2003) defines that the register evaluates the use of the language that is being used in the text. Contact emphasizes how the language is used, familiar or not and easy to understand or not.

The involvement between participants in the text so that it shows the closeness of the distance can be known through the use of the lexis system and the clause system. Based on the data in table 1, the componential analysis in m.republika.co.id news shows that the use of the congruent lexis system is more dominant than the incongruent lexis. This condition indicates that the writer tends to use an oral style of the topic (Wiratno, 2018). Meanwhile, the more dominant use of complex clauses illustrates that the author wants to make the language more familiar through clearly constructed logical relations (Santosa, 2003).

\section{Conclusion}

Based on the description in the discussion of interpersonal meaning in the news entitled "Jokowi Minta Daerah Kawal Vaksinasi Covid-19" in Indonesia which is accessed through the online site m.republika.co.id, it can be concluded that the author only wants to give information to the readers in the news. The author only provides information to the reader as evidenced by declarative clauses more propositions than proposals. However, there is still a clause that carries out the function of the proposal (requesting services). This is because the author wants to describe President Joko Widodo as the President of the Republic of Indonesia as a person who has a distance or a different status, namely a higher status than other participants in the text. In addition, the use of modulation which is more dominant than modalization does not mean that m.republika.co.id media has a higher status than its readers. This is more to make the information clearer and attract the attention of the reader. Furthermore, the use of positive polarity in the text also reveals the participants' positive views in the news text. The author also positions himself more as a party that provides information and places the reader as a member of the academic community who is thought to also have an interest in the information. This is evidenced by the use of lexis and the lexis system in the text, while the use of a complex clause system illustrates that the language used is more familiar and easy to understand so that it shows the closeness of the distance between the writer and the reader.

\section{References}

[1] Chafidzoh, T.F. (2020). The Choice of Mood System in Functional Systemic Linguistics ada Diplomacy Stategy (An Analysis of Classical Arabic Humor Conversation Discourse. ISLAH: Journal of Islamic Literature and History, 1(1), 1-20.

[2] Djatmika. (2012). Perilaku Bahasa Indonesia di dalam Teks Kontrak dari Kacamata Linguistik Sistemik Fungsional. Surakarta: UNS Press.

[3] Halliday, M.A.K. (1985). Language as Social Semiotic. London: Gadjah Mada Edward Arnold.

[4] Halliday, M.A.K., \& Matthiessen, C.M.I.M. (2004). An Introduction to Functional Grammar (3 ${ }^{\text {rd }}$ Ed). London: Hodder Education.

[5] Halliday, M.A.K., \& Matthiessen, C.M.I.M. (2014). Halliday's Introduction to Functional Grammar. Oxon: Routledge.

[6] Hidayat, D.N., Abrizal, \& Alek. (2018). A Multimodal Discourse Analysis of the Interpersonal Meaning of a Television Advertisement in Indonesia. IJEE (Indonesian Journal of English Education), 5(2), 119-126.

[7] Huang, K. (2014). Snip-Snap: An Analysis of Interpersonal Meanings in a Political TV Interview. International Journal of English Linguistics, $4(5), 88-89$.

[8] Khaofia, S. (2018). Modalitas sebagai realisasi makna interpersonal dalam Mata Najwa on Stage "Semua karena Ahok". Prasasti: Jurnal of Linguistics, 3(2), 222-234.

[9] Koutchade, I.S. (2016). The grammar of interpersonal meaning in Wole Soyinka's a play of giants. Mediterranean Journal of Social Sciences, 7(5), 299-309.

[10] Martin, J.R. (1992). English Text; System and stucture. Amsterdam: John Benjamis Publishing Company.

[11] Mahsun. (2012). Metode penelitian bahasa. Jakarta: Rajawali Press.

[12] Moleong, L.J. (2012). Metodologi Penelitian Kualitatif. Bandung : PT Remaja Rosdakarya. 
[13] Mulia, V.L.C. (2015). Pembelajaran dan aplikasi makna interpersonal: Transaksional: proposal sebagai pemahaman aktivitas berbahasa staf housekeeping dan food and beverage service dalam menghadapi permintaan dari tamu asing. UNS Journal of Language Studies, 4(1), $19-27$.

[14] Neezhad, M.R.P dan Tavakoli, F.H. (2013). The Surveying of the Polarity by Mood Adjuncts in Persian Language Based on Functional Grammar Approach. European Scientific Journal, 9(32), 271-280.

[15] Olusanya, A.M. (2014). An Interpersonal Metafunction Analysis of Some Selected Political Some Nigerian Newspaper. Internasional Journal of Humanities and Social Science, 3(8), 165-178.

[16] Santosa, R. (2003). Semiotika Sosial. Surabaya : Pustaka Eureka \& JP. Press.

[17] Santosa, R. (2017). Metode Penelitian Kualitatif Kebahasaan. Surakarta : UNS Press.

[18] Spradley, J.P. (1980). Participant Observation. Florida : Holt, Rinehart and Winston.

[19] Wiratno, T. (2018). Pengantar Ringkas Linguistik Sistemik Fungsional. Yogyakarta: Pustaka Belajar. 